\title{
Women and leadership from a pastoral perspective of friendship
}

\author{
Yolanda Dreyer \\ Department of Practical Theology \\ University of Pretoria
}

\begin{abstract}
The aim of the article is to describe leadership from the perspective of friendship. This perspective highlights a pastoral rather than a power oriented approach to leadership. Such an approach would be compatible with an attitude of service as an essential characteristic of the church. It could also contribute to the healing of church structures that have become entangled in power games. It could lead to the healing of women and other disempowered groups who have for centuries been the victims of the power struggles of church institutions.
\end{abstract}

The world is crying out for the church to be more like the church, to represent the space and place where holiness, meaning, and God can be found, experienced, understood, and reimagined. Yet even at the beginning of a new century, for many, the traditional patterns of religious life remain too patriarchal, inadequate, and even obsolete. For others, the church seems too much in appearance like the world - too busy, too tired, too involved, too demanding, too unstable, too spiritually impoverished, too leadership deprived.

(Stairs 2000:1)

\section{INTRODUCTION}

There is an increasing unease among women and men who experience the leadership of the church as being stuck in a patriarchal mindset, exercising power in an authoritarian, "from-above" manner (see Barr 1969:150). This kind of "hard authority" (Barr 1973:27- 
29) is becoming more and more unacceptable. The alternative presented here is not a total lack of authority and leadership, but rather a specific perspective on authority that would lead to non-patriarchal and non-authoritarian forms of leadership. This could be called "soft authority". A church without authority will be unconvincing and without credibility. Similarly, a church whose authority is based on coercive and abusive power is equally unpersuasive. The latter goes against the very essence of church as the body of Christ existing in the world to serve God and people. The result of this way of exercising authority is the disempowerment of people and, given their history in the world and the church, especially women.

The authority of the church and church leadership is inextricably bound to the authority of the Bible. How the terms "authority" and "leadership" were understood in Biblical times can shed light on the historical heritage and the resulting present practice of the church concerning power and authority. This understanding had an effect on the ways in which the naming of God was done in the Bible as well as in the subsequent theological tradition. One's perspective on the authority of the Bible will determine how the power and authority of God are interpreted.

The terms "hard" and "soft" authority have also been used with reference to the Bible (see Nixon 1977:336). James Barr (1969:150) explains the difference between the words "authoritarian" and "authoritative". "Authoritarian" pertains to the expectation that a command should be obeyed, irrespective of its fairness, because it comes from a powerful position. "Authoritative" refers to the expectation of obedience because adherence to commands is recommendable. Barr (1973:27) applies these concepts to "hard" and "soft" authority. If one's approach to the Bible is that of "hard authority" then the understanding of God's authority will be that of absolute power. The naming of God will reflect this understanding. On the other hand, if one's approach to the Bible is that of "soft authority" God's power will be understood in less absolute terms and the names given to God will reflect this.

The aim of the article is to indicate that leadership can be described form the perspective of friendship since the Bible speaks in these terms about the power of God. The ethics of Jesus, who for me is the human face of God, elucidates the perspective on God as friend in a special way. The idea of leadership from the perspective of friendship 
highlights a pastoral rather than a power oriented approach to leadership. Such an approach would be compatible with an attitude of service as an essential characteristic of the church. It could also contribute to the healing of church structures that have become entangled in power games. It could lead to the healing of women and other disempowered groups who have for centuries been the victims of the power struggles of church institutions.

\section{POWER AND AUTHORITY}

In different eras authority and power were gained in different ways. In an industrial society the possession of capital or the skills with which it can be acquired are ways in which power and authority can be attained. In industrial societies power is often centered in individuals or in more abstract entities such as power structures, the mass media, technical, political and social processes. People also submit to the abstract power and authority of custom and tradition. On an intra-personal level people can be controlled by, for instance, needs, past experience, instincts, as well as reasonable self-control. This constitutes a broad perspective on power and authority (Gunneweg \& Schmithals [1980]1982:10-11; cf Wrong 1979).

Max Weber ([1947] 1968:15-16), however, defines "authority" within narrower confines. He sees authority as "the probability that a command with a given specific content will be obeyed by a given group or persons." He poses the question as to when the authority of the ruler over the ruled is legitimate. Is it ever acceptable and legitimate for some to rule over others, for some people to exert power over others? In James Barr's understanding of hard (authoritarian) and soft (authoritative) authority, "hard authority" would then be seen as unacceptable and "soft authority" as legitimate authority.

The hard or soft approaches to authority were not foreign to the social world of the Bible. These two perspectives were expressed in specific terms. In Latin the relevant terms are dominium, potestas, auctoritas and imperium, and in Greek arche, kuriotes, despoteia and exousia. The rule of the paterfamilias, however, be it the father of the household, the monarch or God, was supposed to be a benevolent rule aimed at protecting the subjects and contributing to their well-being (see Clarke 2000:90-92; Gunneweg \& Schmithals 1982:9). 
In order to distinguish between the more nurturing and the more official aspects of authority (with the innate possibility of the abuse of power), Latin, rather than Western languages, provides the most useful terminology. In Roman thought a distinction was made between the terms potestas and auctoritas. Potestas meant the power of officials was legally invested in their office. Law determined their authority and limits. According to Dionysios of Halicarnasus (see Clarke 2000:87),

the lawgiver of the Romans gave virtually full power to the father over his son, even during his whole life, whether he thought proper to imprison him, to scourge him, to put him in chains and keep him at work in the fields, or to put him to death, and this even though the son were already engaged in public affairs .... And not even at this point did the Roman lawgiver stop in giving the father power over the son, but he even allowed him to sell his son, without concerning himself whether this permission was compatible with natural affection.

Auctoritas, on the other hand, was not based on an office or a given position. It was acquired on account of a person's attributes and capabilities, as well as the recognition of others (see Gunneweg \& Schmithals 1982:16-17). Auctoritas could be the quality of a person with insight, wisdom and charisma, with the power to influence and convince. It could also be the quality of tradition, Holy Scriptures and accepted rules of wisdom. Auctoritas can, therefore, be a great asset to someone with potestas but it does not automatically come with the position. A person with potestas can be someone without auctoritas. "(I)t also follows that in principle potestas has to do with compulsion, while auctoritas always has to do with freedom. Authority exists only where there is free acceptance" (Gunneweg \& Schmithals 1982:17).

Auctoritas provides the safe space in which a person can grow, whereas legal authority provides the order and safety for people to live together. In this sense authority is necessary for human life, while anarchy (a total rejection of all forms of authority) would be detrimental to life. On the other hand, to turn away from authority in order not to remain dependent, is also a natural and normal phenomenon. An irrational and harmful protest against authority is often brought on by a situation where auctoritas has 
been supplanted by potestas (see Gunneweg \& Schmithals 1982:20). This means that force has taken the place of persuasion and coercion has destroyed freedom.

\section{COERCIVE POWER AS DISEMPOWERMENT}

One of the effects of sexism on women has been disempowerment. Negative messages about womanhood have been internalized and external forces have kept women out of positions of power and authority. Women have not been socialized to be leaders. Natural leadership qualities in women have been suppressed by means of labels such as "unfeminine behaviour". Furthermore women have had little opportunity to develop leadership abilities. The church has substantially contributed to the disempowerment and exclusion of women from positions of power and authority. To this day women are excluded from leadership positions in some churches and are rather sparsely represented in others. Nancy Ramsay (2000:276-277) refers to this as "ecclesial distortions of women's experience of power" and describes the effect of these distortions:

Prevailing patriarchal definitions of power have led many women to believe they cannot and perhaps ought not exercise genuine agency. Having internalized a subordinated role early in life, many women cannot imagine it could be appropriate to act in their own interests or that power could be shared. Young women in particular might also think it is dangerous to exercise power, because to do so requires breaking connections and risks the possibly isolating consequences of voicing difference from those with whom they are connected. Ecclesial tradition complicates these fears by its implication in the subordination of women so that, for example, acting on one's own interests could be defined as selfish or proud.

Women's experience of power is rather complex on different levels (see Ramsay 2000:282):

- Intrapsychically women contend with different degrees of internalized subordination that is the result of being woman in a patriarchal culture.

- Professionally women in the church live and work in an environment that was and is complicit in their subordination. 
- Women leaders in the church at the same time assume roles where they are seen as the representatives of God and exercise symbolic power.

Recently the exercising of power and authority is increasingly seen as relational rather than autonomous and aiming at mutual empowerment rather than exerting power over others and controlling (see Ramsay 2000:269; cf LaCugna 1993; Pasewark 1993; Stortz 1993; Johnson 1992). "The experience of dominance by another precludes mutuality, because it signals objectification and manipulation and the silencing effect of the abuse of power" (Ramsay 2000:275). The shift toward mutual empowerment in the exercising of power would open up new possibilities in leadership for women whose development takes place in relationships (Ramsay 270; cf Jordan 1997:20; Surrey 1997a, Surrey 1997b). Such a perspective on leadership has influenced people to use certain names for God.

\section{NAMING GOD, SYMBOLISM AND IMAGERY}

Naming God as male "guarantees the structuring of society, law and the cultural symbolic system in such a way as to keep women subordinate" (Grey 2001:113). According to Marga Bührig (1993:59), "(t)he gift and the power to name the world has been taken away from women by men. In Genesis 2 , Adam is given the right and the opportunity to give names to all living things ... It is a profound human right to be allowed to give names to the world and even to God." Grey (2000:117) argues that a new naming of God "calls for a radically new symbolization and meaning-making process." Male imagery describing God, especially the powerful image of God as Father, has the effect of excluding women and female imagery as a way of symbolizing the divine (see Børresen 1991:197; Grey 2001:9; cf also Ruether 1983). Simone de Beauvoir (1973:16) indicates how maleness acquired normative status for what was human and femaleness was seen as "other than" the norm.

Femaleness was defined relative to, in opposition to, or complementary to maleness. None of these options inspired a free-standing female symbol system, a female cultural imaginary, which could reflect the range of possibilities and complexity of being a woman ... Throughout history this has 
meant the justification for leadership, authority and participation of women in society has had almost no theoretical underpinning.

(Grey 2001:9-10)

Power, authority and leadership have been associated with males and maleness for the greater part of human history. Even though women have reached much higher levels of participation in church and society than ever before in history, "the legacy of thousands of years of exclusive male symbols, and exclusive use of power does not disappear overnight" (Grey 2001:12). There is often much resistance against the introduction of more inclusive imagery (see, for example, the critique of Tolbert [1990:11-12] and Erikson [1994:98, 104] against Schüssler Fiorenza's [1985:53-55] application of a hermeneutics of suspicion). This results in the perpetuation of a system where women as the "other" play supportive roles rather than become full partners in church and society. Imagery and symbols have a powerful effect on shaping the mind-sets of individuals and the views of cultures (cf Conn 1986:3).

The question is, however, whether these mind-sets and systems that dictate women's position in church and culture has been ordained by God or whether they are simply human constructs serving human interests. Rosemary Radford Ruether (1997:37) puts it as follows:

Religion, specifically the Christian tradition with its roots in the Hebrew and Greco-Roman worlds, has been faulted as a prime source of the culturalsymbolic patterns, which have inferiorized women and nature. The patriarchal God of the Hebrew Bible, defined as outside and over against the material world as its Creator and Lord, when fused with Greek philosophical dualisms of spirit and matter, is seen as the prime identity myth of the Western ruling class male. He has made this God in the image of his own aspiration to be both separate from and ruling over the material world, as land and animals or non-human "resources", and as subjugated groups of humans.

It is not possible for human beings to have an "accurate" or "correct" idea of God. All God-images are human constructs and therefore need to be consciously analyzed for 
distortions that could cause harm. Jane Schaberg (1994:280) demonstrates that "biblical and traditional images of women go hand in hand with the denial of women's rights to control their own bodies and their lives." Awareness of human imperfection directs the attention yet again to the message of Jesus in the Bible in order to critically examine human knowledge of and statements concerning God.

In the Bible a great variety of imagery to describe God is to be found. Some images are used in certain eras and disappear in subsequent times. On account of the distance of time and a difference between the cultures there is discontinuity between Biblical times and the present time. On the other hand there is continuity between believers of ancient times and of today listening for the voice and direction of God in their lives. When we listen to how the people of long ago spoke about God and how their understanding of God formed their identity, we too are seeking our own identity and searching for ways to speak about God's presence in our lives. Though human witness of God is imperfect and has originated within imperfect social structures, we nonetheless listen to this witness in search of a better understanding of God, our world and ourselves. Elisabeth Schüssler Fiorenza (1985:41) puts it as follows:

\footnotetext{
Rather than understand the text as an adequate reflection of the reality about which it speaks, we must search for clues and allusions that indicate the reality about which the text is silent. Rather than take androcentric texts as informative "data" and accurate "reports", we must read their "silences" as evidence and indication of that reality about which they do not speak. Rather than reject the argument from silence as a valid historical argument, we must learn to read the silence of androcentric texts in such a way that they can provide "clues" to the egalitarian reality of the early Christian movement.
}

When speaking about God, people cannot but use terms known to them in their culture. So the Bible describes God as having hands, feet, eyes and a mouth. God walks, sits and lives in an abode. God laughs, gets angry and has regrets. But the Bible also speaks of God in such a way as to emphasize the mystery and otherness of God. Isaiah 40-55 shows God's incomparability as well as God's proximity (see Van Wijk-Bos 1995:11). In a culture where powerful people were all male, authors witnessing to Gods strength 
and power would naturally do so by making use of imagery with a connotation of power in their culture. In Biblical times kings, patriarchs, masters, military leaders and judges were people with power, honour and status. These people were all male. Female persons had no power, honour or status in the culture. Therefore it is understandable that female imagery is not abundantly represented in Scripture. On the other hand, given the invisibility, voicelessness and low status of women in the culture, the existing female imagery in the Bible and especially with regard to God is noticeable (Mollenkott 1992:90; cf Mollenkott 1983). Israel lived in the presence of God and experienced God as actively participating in their history. In their attempt to describe their experience of God and their relationship with God they made use of metaphors, symbols and analogies from their cultural world. God is involved with people (see Coll 1994:32).

An image differs from the reality to which it refers. Language functions comparatively. Though God is compared to something or someone human, God does not equal that person or thing. The danger of a direct identification of God with how humans speak about God is always present. That would mean capturing God in and confining God to human concepts. It is therefore necessary to be aware "that language for God is language of comparison and not of identification" (Van Wijk-Bos 1995:35; cf Caird 1980:144; Mc Fague 1985; Johnson 1994:113; Wren 1989:84-110; Soskice 1985).

Metaphors are not definitions or descriptions. They convey something but not everything about a person or topic. Metaphorical language presents the possibility of speaking about God, but has very specific limitations. Because images are taken from human experience they will change as the experience changes (see Ricoeur 1974:26, 38, 42-43). The meaning of images and symbols will change as human experience changes. Some images will lose their saying power and disappear altogether. "Symbols die because they can no longer produce response in the group where they originally found expression" (Tillich 1957:431). Images such as "king", "lord", and (military) "general" have different connotations today than in Biblical times. Other more relevant images taken from human experience should replace those that have become redundant (see Coll 1994:40-44). 
Concerning the correlation between God-imagery and women's identity, their possibility for authentic life before God and for leadership functions in society the following can be posited:

- Exclusively male speech about God deprives women of the opportunity of identifying with God as men can and that affects their socialization and identityformation.

- Some images used for God have become irrelevant because human experience has changed.

- Some images used for God have become problematic because of the negative connotations they have acquired in today's society. Imagery concerning power and male domination would be an example.

\section{THE POWER OF GOD AS BASIS FOR LEADERSHIP}

\subsection{Leadership from the perspective of friendship}

In traditional theology the image of the almighty all-powerful God emphasizes God's transcendence and the distance between God and people, who are prone to brokenness and powerlessness. This places God firmly out of the reach of human beings. Distance and separation are the result. There is, however, another side to this story. Those human beings who can identify with God's maleness and the wielding of power in their everyday lives could exercise their leadership and authority in the image of the almighty and allpowerful One. Women who cannot identify with maleness and whose concrete reality mostly does not include wielding power over others by "ruling" and controlling, need to find another perspective on leadership, power and authority if they are to participate.

According to Carter Heyward (1982:7), women need to move away from the image of God as a "distant controlling device manufactured in the minds of men who have bent themselves low before ideals of changeless Truth, deathless Life, pure spirit, perfect reason and other qualities associated with the changeless God." Heyward finds God's power elsewhere. She sees God's power as "relational power" rather than the 
patriarchal power of might and violence. This is a power of sensitivity, compassion, empathy, affiliation and bonding (Grey 2001:51; cf Grey 1989:103-104). From this source of power as "empowerment", as a healing, life-enhancing and liberating force, leadership and authority can set out in a new direction. Leadership seen from the perspective on God as friend is such a direction.

Friendship took different forms in different times. The topic was widely discussed in the literature of the Greco-Roman world. The prevalent ideas on friendship had an impact on the writings of the New Testament. Though the term "friendship" might not be explicitly used in the New Testament, the underlying ideas concerning friendship can often be recognized and can facilitate a better understanding of the New Testament (see Keener 2000:380).

With the present-day understanding of equality as a prerequisite for communication (see Habermas ([1981] 1984; cf Maddox 1985:524), mutuality in a symmetrical relationship would probably be regarded as a necessary requirement for friendship. So also will friendship be regarded as a personal relationship. In antiquity this, however, was not always the case. Friendships could be either a relationship of equality or dependence, personal or impersonal (Keener 2000:381).

The term "friendship" is often used in a political context. Keener (2000:381) observes, for instance, that "(w)hereas Aristotle notes friendships based on goodness, pleasure or utility (Aristotle Eth Eud 7.2.9-13, 1236a; 7.10.10, 1242b; Eth Nic 8.13.1, $1162 \mathrm{ab}$ ), he assigns it most to utility" (Aristotle Eth Eud 7.2.14, 1236a; cf also Schroeder 1997:35-57). "Friendship" was also generally used to denote treaties and other forms of political associations. Somewhat closer to the personal sphere, but still essentially political, is the use of "friendship" to describe familial relationships that have been forged for their political usefulness. The political and essentially unequal relationship between a patron and a client was often also called "friendship" (see Sherk 1988:235).

A less hierarchical and more equal idea of friendship did, however, also exist among people in antiquity, for example people of equal status such as the members of a guild, people of a similar age and of the same sex (see Stowers 1986:28-30, 39, 60; cf Gould 1963:143-145). As far as equality in these friendships is concerned, it is probably still rather different to what is meant by equality today. Keener (2000:382) puts it as 
follows: "Although Roman patronal friendship made at best a vague pretense to equality, the traditional Greek image of friendship, even when related to benefaction, demanded at least the idea of equality." Though the ideal of equality was strong and it was indeed a great honor to the person regarded by the friend as an equal, friendships in antiquity were not just free voluntary relationships. It entailed certain duties or "obligations and expectations" (Meeks1983:30).

The characteristics of friendship as described in the literature of antiquity do not differ too much from what would today be regarded as trustworthy friendship (see Keener 2000:383-384):

- to be able to entrust secrets and confidences to a friend (Isocrates Dem 24-25; Or 1; Josephus Ag Ap 2.28 parag 207; Philo Sobr 55; Sir 6:9; 22:22; 27:17);

- to have confidence (pistis) in the friend and in the duration of the friendship (Aristotle Eth Eud 7.2.40, 1237b);

- to speak plainly and truthfully rather than just saying what the person would want to hear (Isocrates Ad Nic 28, Or 2; Seneca Dial 10.15.2);

- to do for friends what would be the best for them (Aristotle Rhet 1.5.16,1361b);

- sharing what one has with a friend (Plutarch Flatterer 24, Mor 65AB; Diogenes Laertius Vit 7.1.124, LCL 2:228-229);

- sacrificing for a friend even to the point of giving one's life (Diodorus Siculus Bib Hist 10.4.4-6; Epictetus Disc 2.7.3).

Friendships between human beings and deities are also described in the literature of antiquity, including the Bible. Though in this case one would expect a friendship based on the patron-client relationship of inequality, Keener (2000:384) interestingly remarks: "The supreme example of patronal friendship in ancient sources might be thought to be discovered in passages referring to friendship with God. Surprisingly, however, it is not the patronal but the voluntary, reciprocal elements of the relationship that dominate many of these texts." Both Abraham (2 Chron 20:7) and Moses (Ex 33:11) were called "friends of God" and in John 15:14-15 Jesus calls the disciples his friends. In these friendships trust is important, secrets are entrusted to the friend, all one has is shared with the friend, 
and Jesus is willing to sacrifice his life for his friends. When Jesus himself is no longer present, the Spirit will be the one who continues to communicate special knowledge to God's friends (Jn 16:13-15). Luke often refers to friends helping one another and sharing what they have in both the Gospel of Luke and in Acts (see Mitchell 1997:236-257). Keener (2000:386; cf Mitchell 1997:237-249) observes:

\begin{abstract}
Although Acts 2:44-47 does not employ the term friendship, its emphasis on shared possessions would evoke for many Greek readers the ideal of friendship held by various other communities, at the same time challenging the usual expectation of reciprocity in ancient friendship. In contrast to the patronal model of friendship, higher-status members of Luke's audience are to use their possessions to provide benefaction without expecting reciprocation, even in honor ... Luke thus pushes the notion of equality in friendship further than traditions of patronage.
\end{abstract}

A different conception of the power, rule and authority of God can lead to a different practice in the leadership that is exercised in God's name and in the service of God. In classical theism God is the king ruling over God's dominion from a distance. This mighty God intervenes from above in human history and wields coercive power (cf Grey 2001:90-92). The power of God, seen from the perspective of friendship, is a different kind of power altogether. This is the power of compassion (cf Farley 1990) manifested in the ethics of Jesus.

\title{
3.2 Jesus' ethics
}

Ethics pertains to the values of a group or an individual embedded in a group. The ethics of Jesus is expected to be transparent in the values of the early Jesus groups. The basic values of a group reflect its deepest convictions. Formally these values are articulated in the texts of the community. Theissen (1999:81) states in this regard that "basic values prove to be basic values by shaping other values and norms. They serve as meta-values and meta-norms for other ethical statements" (Theissen's italics). He considers humility (the renunciation of status) and love, for example, to be basic values of the early Jesus groups. These basic values shape all relationships. As far as the relationship with the 
neighbour is concerned, the boundaries between in-group and out-group (horizontal boundaries) and those between higher and lower status positions (vertical boundaries) are crossed.

In Theissen's (1999:81) view "this twofold crossing of boundaries can be demonstrated throughout the primitive Christian ethic, even where there is no direct mention of either love or humility". The crossing of the vertical boundaries (of position and status) takes an interesting turn in the Christian ethic. The ideas of neighbourliness and humility come from the lower echelons of society. But in the Jesus movements people who live according to these values are given high status by God. So a value from below makes it to the sphere of status and position. The opposite also happens. The values of the ethic of rule found among the upper classes are made accessible to the common people. Theissen (1999:82) calls it the "democratization' of an ancient aristocratic ethic".

The Jesus saying that it is better to give than to receive (Acts 20:35) was a "general maxim of benefactors in antiquity and ... it can first be demonstrated as a maxim for royal disposition and behavior" (Theissen 1999:90; cf also 1995a:195-215). It was an aristocratic value to be a benefactor to the people and to use one's wealth for the benefit of the community (cf Bolkestein [1939] 1967). Patrons did good works for those whose loyalty they wanted to secure and as a means to demonstrate their position and status in society. The fame their good works brought them, ensured that they would be remembered and praised even after their death. Their benevolence did, however, not extend to the poor. In the Christian ethic this value from above, an aristocratic value, met with the value of neighbourliness, a value from below, a value of the little people, and the fusion of the two became a Christian value. "However, this changes the purpose of the benefaction which is no longer to safeguard rule or to increase public prestige. It is now to provide for all in a communitarian fellowship in which all support one another (Theissen 1999:91; cf Hengel 1974:60-73; Theissen 1995b:689-711). In the Jesus group those who suffered and those who served, not those who ruled, became the persons with high status. This early Christian perspective is articulated in Luke 22:25-26: 
And Jesus said to them,

"The kings of the Gentiles lord it over them;

and those who exercise authority over them

call themselves Benefactors (euergetai).

But you are not like that.

Instead, the greatest among you should be like the youngest,

and the one who rules like the one who serves.

\section{LEADERSHIP - PASTORAL IN ITS APPROACH}

Feminist theology sees God's power not as hierarchical, but personal (see LaCugna 1993:94). God's power serves love (Ramsay 2000:281). Leadership drawing from this source of power would show a different face: "Compassion is not a one-sided, paternalistic pity, but is a form of love, the disposition to love in a world filled with suffering, always respecting the integrity of the other. Compassion is the power that drives to justice, beyond the narrow limits of a legalism which contents itself with punishing the wicked" (Grey 1993:115). Should leadership within the Body of Christ tap into this source of power a pastoral approach would be an appropriate response not only to human suffering but also to human fallibility and the tragedy of human life. Too often human fallibility is met with punishment rather than compassion. The reason given by church leadership for such a stance being a fear of "condoning sin" if the sinner is forgiven rather than punished. This view leaves no room for a more nuanced perspective on the tragic dimension of human life in the sense of the "moral paradox that beings who want goodness cannot remain uncontaminated by evil" (Grey 2001:95; cf also Sands 1994:63).

The power of God understood not as strength and might, not as coercive intervention, but as participation, compassion and empathy, opens the way to an understanding of the vulnerability of God. Jesus, the human face of God, was not the mighty messiah vanquishing the enemy with military force as expected. Jesus emptied himself, suffered as a human being, his fragile body was mutilated and this resulted in his death. "Openness to divine power is precisely through the vulnerability that God and humanity share with the process of sentient life" (Grey 2001:98). This vulnerability is not weakness, but rather is the strength of Christianity, for God's power is strongest when human beings are weak. Leadership unashamedly based on the recognition of human 
weakness, frailty, vulnerability and tragedy will refrain from coercive power, judgement and punishment. It will be pastoral in its approach, intent upon healing of and hope for human brokenness. Where coercive power and paternalistic authoritarianism are repulsive to women who have so long been on the receiving end, the female half of humanity could gladly participate in this kind of leadership and empowerment of people. For this kind of leadership "authenticity in relation" is necessary. "Authenticity in the practice of ministry reflects an interactive and evolving relational and theological competence. It is felt internally and conferred publicly as the authority to practice ministry as a religious leader among the people of God" (Ramsay 2000:278).

\section{Works consulted}

Barr, J 1969. The authority of the Bible. Ecumenical Review 21(92), 135-166.

Barr, J 1973. The Bible in the modern world. London: SCM Press.

Børresen, K E 1991. God's image, man's image? Patristic interpretation of Genesis 1:27 and I Cor 11:7, in Børresen, K E (ed), Image of God and gender models in Judaeo-Christian tradition. Oslo: Solum Forlag.

Bührig, M 1993. Woman invisible: A personal odyssey in Christian feminism. Valley Forge, PA: Trinity Press International.

Caird, G B 1980. The language and imagery of the Bible. Philadelphia, PA: Westminster.

Clarke, A D 2000. Serve the community of the church: Christian leaders and ministers. Grand Rapids, MI: Eerdmans.

Coll, R A 1994. Christianity and feminism in conversation. Mystic, CT: Twenty-Third Publications.

Conn, J W 1986. Introduction, in Conn, J W (ed), Women's spirituality: Resources for Christian development, 1-8. New York, NY: Paulist.

De Beauvoir, S 1973. The second sex. Harmondsworth: Penguin.

Eriksson, A-L 1994. The meaning of gender in theology: Problems and possibilities. Stockholm: Gotab. (Women in Religion 6.)

Farley, W 1990. Tragic vision and divine compassion: A contemporary theodicy. Louisville, KY: Westminster/John Knox Press. 
Gould, T 1963. Platonic love. London: Routledge \& Kegan Paul.

Grey, M 1989. Redeeming the dream: Christianity, feminism and redemption London: SPCK.

Grey, M 1993. The wisdom of fools: Seeking revelation today. London: SPCK.

Grey, M 2001. Introducing feminist images of God. Sheffield: Sheffield Academic Press. (Introductions in Feminist Theology.)

Gunneweg, H J \& Schmithals, W [1980] 1982. Authority, tr by J E Steely. Nashville, TN: Abingdon. (Biblical Encounters Series.)

Habermas, J [1981] 1984. The theory of communicative action, Vol 1: Reason and the rationalization of society, tr by $\mathrm{T}$ McCarthy. Boston, MA: Beacon.

Hengel, M 1974. Property and riches in the early church. London: SCM.

Heyward, C 1982. The redemption of God: A theology of mutuality. Washington, DC: University of America Press.

Johnson, E A 1994. She who is: The mystery of God in feminist theological discourse. New York, NY: Crossroad.

Jordan, J V 1997. A relational perspective for understanding women's development, in Jordan, J V (ed), Women's growth in diversity. New York, NY: Guilford.

Keener, C S 2000. sv Friendship, in Evans, G A \& Porter, S E (eds), Dictionary of the New Testament background, 380-388. Leicester: Intervarsity Press.

LaCugna, C M (ed) 1993. Freeing theology. New York, NY: Harper Collins.

Maddox, R L 1985. Contemporary hermeneutic philosophy and theological studies. Religious Studies 21(4), 517-529.

McFague, S [1982] 1985. Metaphorical theology: Models of God in religious language. Philadelphia, PA: Fortress.

Meeks, W A 1983. The first urban Christians: The social world of the apostle Paul. New Haven, CT: Yale University Press.

Mitchell, A C 1997. "Greet the friends by name": New Testament evidence for the Greco-Roman topos on friendship, in Fitzgerald, J T (ed), Greco-Roman perspectives on friendship, 225-262. Atlanta, GA: Scholars Press. (SBLRBS 34.)

Mollenkott, V R 1983. The divine feminine: The biblical imagery of God as female. New York, NY: Crossroad. 
Mollenkott, V R 1992. Sensuous spirituality: Out from fundamentalism. New York, NY: Crossroad.

Nixon, R 1977. The authority of the New Testament, in Marshall, I H (ed), New Testament interpretation, 334-350. Exeter: Paternoster Press.

Pasewark, K 1993. A theology of power. Minneapolis, MN: Fortress.

Ricoeur, P 1974. Philosophische und theologische Hermeneutik, in Ricoeur, P \& Jüngel, E, Metapher: Zur Hermeneutik religiöser Sprache, 22-24. München: Chr Kaiser Verlag. (Evangelische Theologie Sonderheft.)

Ruether, R R 1983. Sexism and God-talk. London: SCM.

Ruether, R R 1997. Ecofeminism: First and third world women. American Journal of Theology \& Philosophy 18(1), 33-45.

Sands, K 1994. Escape from paradise. Minneapolis, MN: Fortress.

Schaberg, J 1994. [The] A feminist [contribution] experience of historical Jesus scholarship, in Lawler, J G (ed), The 1994 Annual of Hermeneutics \& Social Concern, 266-285. New York, NY: Continuum.

Schroeder, F M 1997. Friendship in Aristotle and some peripatetic philosophers, in Fitzgerald, J T (ed), Greco-Roman perspectives on friendship. Atlanta, GA: Scholars Press. (SBLRBS 34.)

Schüssler Fiorenza, E 1985. In memory of her: A feminist theological reconstruction of Christian origins. New York, NY: Crossroad.

Sherk, R K (ed) 1988. The Roman Empire: Augustus to Hadrian. New York, NY: Cambridge University Press. (TDGR 6.)

Soskice, J M 1985. Metaphor and religious language. Oxford: Clarendon.

Stairs J 2000. Listening for the soul: Pastoral care and spiritual direction. Minneapolis, MN: Fortress.

Stortz, M E 1993. Pastor power. Nashville, TN:Abingdon.

Stowers, S K 1986. Letter writing in Greco-Roman antiquity. Philadelphia, PA: Westminster. (LEC 5.)

Surrey, J L 1991a. The self-in-relation: A theory of women's development, in Jordan, J V et al, Women's growth in connection. New York, NY: Guilford. 
Surrey, J L 1991b. The relational self in women: Clinical implications, in Jordan, J V et al, Women's growth in connection. New York, NY: Guilford.

Theissen, G 1995a. “Geben ist seliger als nehmen” (Apg 20, 35): Zur Demokratisierung antiker Wohltätermentalität im Urchristentum, in Boluminski, A (Hrsg), Kirche, Recht und Wissenschaft: Festschrift für Albert Stein, 195-215. Neuwid: Luchterhand.

Theissen, G 1995b. Urchristlicher Liebeskommunismus: Zum "Sitz im Leben” des Topos in Apg 2, 44 und 4, 32, in Fornberg, T \& Hellholm, D (eds), Text and contexts: Biblical texts in their textual and situational contexts, 689-711. Oslo/Copenhagen: Scandinavian University Press.

Theissen, G 1999. A theory of primitive Christian religion, tr by J Bowden. London: SCM.

Tillich, P 1957. Dynamics of faith. New York, NY: Harper \& Row.

Tolbert, M A 1990. Protestant feminists and the Bible: On the horns of a dilemma, in The pleasure of her text: Feminist readings of biblical and historical texts. Philadelphia, PA: Trinity Press International.

Van Wijk-Bos, J W H 1995. Reimaging God: The case for Scriptural diversity. Louisville, KY: John Knox.

Weber, M [1947] 1968. Max Weber: On charisma and institution building. Selected papers edited and with an introduction by $\mathrm{E} \mathrm{N}$ Eisenstadt. Chicago, IL: University of Chicago Press.

Wren, B 1989. What language shall I borrow? God-talk in worship: A male response to feminist theology. New York, NY: Crossroad.

Wrong, D H 1979. Power: Its form, bases, and abuses. New York, NY: Harper \& Row. 